\title{
Menippean Satire Reconsidered From Antiquity To The Eighteenth Century
}

Excellent book is always being the best friend for spending little time in your office, night time, bus, and everywhere. It will be a good way to just look, open, and read the book while in that time. As known, experience and skill don't always come with the much money to acquire them. Reading this book with the PDF menippean satire reconsidered from antiquity to the eighteenth century will let you know more things.

As known, adventure and experience about lesson, entertainment, and knowledge can be gained by only reading a book. Even it is not directly done, you can know more about this life, about the world. We offer you this proper and easy way to gain those all. We offer many book collections from fictions to science at all. One of them is this menippean satire reconsidered from antiquity to the eighteenth century that can be your partner.

What should you think more? Time to get this [PDF? It is easy then. You can only sit and stay in your place to get this book. Why? It is on-line book store that provide so many collections of the referred books. So, just with internet connection, you can enjoy downloading this book and numbers of books that are searched for now. By visiting the link page download that we have provided, the book that you refer so much can be found. Just save the requested book downloaded and then you can enjoy the book to read every time and place you want.

It is very easy to read the book in soft file in your gadget or computer. Once more, why should be so difficult to get the book if you can choose the easier one? This website will ease you to select and choose the best collective books from the most wanted seller to the released book recently. It will always update the collections time to time. So, connect to internet and visit this site always to get the new book every day. Now, this menippean satire reconsidered from antiquity to the eighteenth century is yours.

\section{Popular Books Similar With Menippean Satire Reconsidered From Antiquity To The Eighteenth Century Are Listed Below:}

